\title{
Salinity regulation of copepod egg production in a large microtidal estuary
}

\author{
Danilo Luis Calliari ${ }^{1,2}{ }^{\infty}$, Noé Espinosa ${ }^{2}$, Mariano Martínez ${ }^{2,3}$, Laura M. Rodríguez-Graña ${ }^{2}$ \\ ${ }^{1}$ Facultad de Ciencias, Universidad de la República, Oceanografía y Ecología Marina \\ (Montevideo -Montevideo - Uruguay) \\ ${ }^{2}$ Centro Universitario Regional del Este-Universidad de la República, Ecología Funcional deEcosistemas Acuáticos \\ (Rocha - Rocha - Uruguay) \\ ${ }^{3}$ Alfred Wegener Institute, Helmholtz Centre for Polar and Marine Resaerch, Department of Functional Ecology \\ (Bremerhaven - Bremen - Germany) \\ *Corresponding author: dcalliar@fcien.edu.uy
}

\section{Abstract}

Salinity is a key variable for ecological processes in estuaries. Acartia tonsa is a typical estuarine copepod whose responses to salinity have been thoroughly studied in the laboratory. However, results cannot be extrapolated to the field, and formal comparisons between lab and field responses to salinity were not attempted. Here we compare lab-based with field copepod egg production rates (EPR) from the Río de la Plata estuary (RPE), with focus on A. tonsa. Field work was conducted between 2009 and 2011 in the mixing zone of the RPE. Water temperature, salinity and chlorophyll-a varied over ample ranges (temperature: $10.54-24.56^{\circ} \mathrm{C}$, salinity: 2.83 - 32.99, chlorophyll-a: $0.62-7.27 \mathrm{mg} \mathrm{m}^{-3}$ ). A. tonsa was the strongly dominant species. EPR ranged between 6.7 and 95.7 eggs female ${ }^{-1}$ day $^{-1}$, and correlated to salinity, temperature (weakly), but not to chlorophyll. The relationship between $A$. tonsa's $\mathrm{EPR}\left(\mathrm{EPR}_{\mathrm{AT}}\right)$ and salinity was consistent with that obtained under laboratory conditions: a humped pattern with a maximum at intermediate salinities. However, differences were also evident, e.g., higher $\mathrm{EPR}_{\mathrm{AT}}$ was measured in the field. We speculate that discrepancies derive from nutritional differences between field and reference (laboratory) data sets. Besides salinity, food quality and quantity may be first order drivers of $A$. tonsa's productivity in the RPE.

Descriptors: Copepods, Estuary, Acartia tonsa, Egg production rate, Río de la Plata.

\section{INTRODUCTION}

The dilution of marine waters by freshwater runoff is characteristic of most estuaries. The resulting salinity gradient is a major structuring factor for physical, chemical and biological processes in such ecosystems (Bianchi, 2007). Low and variable salinity imposes stressful conditions for both marine and freshwater fauna (Attrill, 2002), and low taxonomic diversity in brackish areas of estuaries generally match high biomass and biological production (Day et al., 2013). Estuarine copepod communities are typically dominated by a limited number of eurihaline species. Within those, Acartia tonsa is commonly an important component in subtropical and warm temperate

Submitted on: 15/May/2019

Approved on: 23/June/2019

http://dx.doi.org/10.1590/s1679-87592019026706708 latitudes in both the Atlantic and Pacific coasts of America (Hoffmeyer, 2004; Muxagata et al., 2012; Aguilera et al., 2016; Rice et al., 2015) and also in coastal waters and estuaries of Europe (Cervetto et al., 1995; Leandro et al., 2007).

A. tonsa is well known for its tolerance to wide salinity conditions, and has been used as a model organism for investigation of vital responses to salinity. Results derived from experimental studies under laboratory conditions showed that $A$. tonsa tolerates extremely ample salinity ranges (Lance, 1964; Cervetto et al., 1999; CastroLongoria, 2003), rapid salinity increments (Hubareva et al., 2008), and osmotic shocks (i.e., instantaneous changes, Calliari et al., 2009a). A. tonsa hyperregulates in waters with osmolarity below that corresponding to a salinity of approximately 32 (Lance, 1965). The metabolic balance of $A$. tonsa was shown to be nearly stable under salinities between 2 and 32: egg production rate by $A$. tonsa 
$\left(\mathrm{EPR}_{\mathrm{AT}}\right)$ and gross growth efficiency followed a humped pattern with best performance at the intermediate salinity (20), consistent with its estuarine affinity (Calliari et al., 2006). Available evidence thus provide a clear picture of A. tonsa responses to salinity in the laboratory.

The metabolic responses and growth of $A$. tonsa when subjected to salinity gradients in nature are less explored and it is not safe to assume identical patterns to those observed in the laboratory. Under controlled laboratory conditions measured responses can be compromised due to simplifications inherent to such approaches (Båmstedt et al., 2000; Runge and Roff, 2000; Ikeda et al., 2000). Thus, it is important to explicitly assess the extent to which patterns observed in the laboratory are also valid in nature. Feeding and EPR by A. tonsa under field conditions have been measured on many occasions (e.g., Castro-Longoria, 2003; Berasategui et al., 2016), but direct and explicit comparison with laboratory results were not attempted.

Knowledge on copepods' vital rates in the Rio de la Plata estuary (RPE) is very limited. That is a large scale estuary characterized by high primary production and commercial fish catches (see below). It would be therefore expected that intermediate consumers which link producers and fish also attain high production levels. Information so far available is limited to a short-term 4-months study in nearshore waters at Montevideo, on the northern bank of the RPE (Calliari et al., 2004), and a snapshot evaluation in open waters encompassing oligo and mesohaline areas of the estuary (Derisio et al., 2014). Both studies focused on $A$. tonsa, the strongly dominant species there, and surprisingly both reported very low $\mathrm{EPR}_{\mathrm{AT}}$. Clearly, more information is required in order to draw valid conclusions about the productivity of copepods in that ecosystem.

The goal of this paper is thus two-fold: i.- to contribute new information in order to characterize copepods' EPR, and particularly that by $A$. tonsa, the dominant copepod species in the brackish region of the RPE; and ii.- to evaluate the relationship between $\mathrm{EPR}_{\mathrm{AT}}$ and salinity in situ, in order to compare it with laboratory estimates obtained under controlled conditions.

\section{METHODS}

\section{RIO DE LA PLATA ESTUARY}

The RPE is a large and turbid microtidal estuary on the subtropical South West Atlantic formed by the confluence of Paraná and Uruguay rivers. With a compound basin of 3.1 million $\mathrm{km}^{2}$ and an annual average flow of
20000-25000 $\mathrm{m}^{3} \mathrm{~s}^{-1}$ (Guerrero et al., 1997) that is the main freshwater point source to the South Atlantic Ocean. The RPE has high ecological, societal and economic relevance; it provides services like navigation, recreation, drinking water supply and fishing. Several fish species use the RPE as nursery and/ or spawning ground (Acha et al., 1999; Norbis and Verocay, 2005). Artisanal and industrial scale fleets of Argentina and Uruguay harvest scienids (Micropogonias furnieri, Cynoscion gutucupa), engraulids (Engraulis anchota) and clupeoids (Brevoortia aurea) among other (Lercari et al., 2015). The significance of the RPE extends beyond the immediate region, as biogeochemical processes within the estuary likely affect particulate and dissolved matter fluxes between the continent and the Atlantic ocean.

Most conspicuous features along the main axis of the RPE are salinity and turbidity gradients (Nagy et al., 1998; Guerrero et al., 1997). Salinity changes between zero and approx. 30 over a distance of $140 \mathrm{~km}$. A turbidity maximum develops in the oligohaline region, and the transition between oligo and mesohaline conditions is marked by a sharp decrease in the load of suspended particles. Primary production rates are relatively high, especially in the oligo and mesohaline areas (Calliari et al., 2018).

Few species comprise the zooplankton community. Composition changes from freshwater assemblages in the upper reaches, to estuarine in the mixing zone, to coastalmarine assemblages at the outermost zone (Berasategui et al., 2006; Derisio et al., 2014). Oligo and mesohaline regions are strongly dominated by $A$. tonsa; other occasionally abundant taxa in the same area of the RPE are Paracalanus parvus and Parvocalanus crassirrostris (Berasategui et al., 2006; Paul and Calliari, 2017). This study focuses on the outer region of the RPE off Montevideo (Fig. 1). On a climatological scale the sampling area lays within the transition between oligo and mesohaline conditions. But according to synoptic wind and runoff salinity may fluctuate between nearly freshwater (i.e., salinity $<1$ ), to near full-strength marine.

\section{DATA COLLECTION}

Eight cruises were performed off Montevideo near the maximum turbidity zone during times representing the four seasons between 2009 and 2011 (Table 1, Fig. 1). Each cruise comprised three stations along an approximately $12 \mathrm{~km}$ transect where salinity and temperature were recorded with an SBE 19V2 CTD profiler (Seabird, Washington, USA); quality control and post-processing of CTD records were performed 


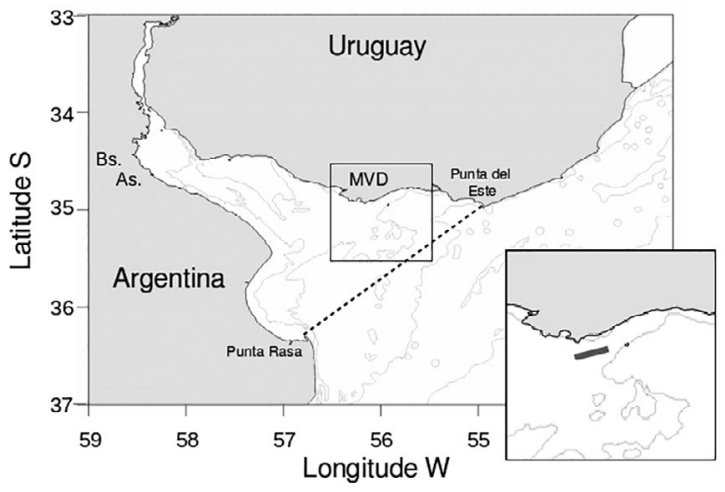

Figure 1. Study area. Upper panel: Rio de la Plata estuary and sampling area. Grey lines are isobaths corresponding to 5, 10,20 and $50 \mathrm{~m}$. Dotted straight line represents the official limit between the Rio de la Plata and the continental shelf. The inset expands the box in the bigger map.

using Seasoft processing modules according to manufacturer recommendations (Seasoft manual). Water column depth at sampling stations ranged between 8 and $12 \mathrm{~m}$. Subsurface samples were taken with 5-L Hydrobios PWS bottles for fluorometric chl-a determination according to Parsons et al. (1984) and Wasmund et al. (2006); 50mL aliquots were filtered through $\mathrm{GF} / \mathrm{F}$ and the pigments extracted in $96 \%$ ethanol for $24 \mathrm{~h}$ in the dark at $4^{\circ} \mathrm{C}$. The fluorescence of the extract was read before and after acidification $(\mathrm{HCl} 1.2 \mathrm{~N}$ ) in a Turner 111 fluorometer calibrated against pure chl-a extract (Sigma).

Quantitative zooplankton samples were collected by subsurface (upper 2 - 3m of the water column) horizontal tows of a $60 \mathrm{~cm}$ mouth diameter plankton net fitted with a $90 \mu \mathrm{m}$ mesh and a flowmeter. Samples were preserved in a $4 \%$ formaldehyde solution (final concentration) for later analysis. Live samples for estimation of copepods EPR were collected by slow tows of the same net fitted with a modified non-filtering cod-end. These samples were immediately diluted in $15 \mathrm{~L}$ thermally-insulated buckets filled with in situ water and transported to the laboratory for sorting and incubations. At the laboratory and within two hours of collection live samples were screened and healthy-looking adult females of dominant species (usually $A$. tonsa) were picked under low magnification microscope and placed in blue-cap bottles that were incubated standing in the dark under temperature conditions close to ambient (within $1^{\circ} \mathrm{C}$ ). Incubation medium was in situ water pre-filtered by $65 \mu \mathrm{m}$ in order to remove copepod eggs, nauplii or predators that might have been present in the natural water. After $24 \mathrm{~h}$ the contents of the bottles were sieved $(65 \mu \mathrm{m})$ and examined under the microscope: status of the females was checked (live/ dead condition, any abnormal behavior was recorded) and the number of eggs was counted. Incubations corresponding to the first four cruises consisted in three females in $250 \mathrm{~mL}$ bottles, with five replicates; from cruise five and onward incubations consisted of single females in $125 \mathrm{~mL}$ bottles, with ten replicates. The change in the incubation protocol responded only to the interest in exploring individual variability in EPR among females (not reported here). The average of replicate bottles was taken as the EPR response for the environmental condition observed (sampling station and date). EPR was expressed as eggs produced per female per day.

\section{DATA ANALYSES}

Profiles of temperature and salinity were graphically inspected and representative values for the upper water column were obtained as the arithmetic average over the surface mixing layer. These were used as the reference salinity and temperature for exploring their relationship with EPR. The analysis of the relationship between EPR and environmental variables proceeded in two steps: In a first step the general pattern in the relationship between EPR (response variable) and temperature, salinity and chlorophyll-a (predictive variables) was explored by Generalized Additive Models

Table 1. Cruise number, date, season and range of surface salinity, temperature and chlorophyll-a during each cruise.

\begin{tabular}{lclccc}
\hline Cruise & Date & Season & Temp_s & Sal_s & Chl-a \\
\hline 1 & 5 Aug 2009 & Winter & $10.54-10.75$ & $12.25-21.67$ & $0.97-2.03$ \\
2 & 18 Aug 2009 & Winter & $11.52-12.29$ & $4.66-5.27$ & $2.76-3.73$ \\
3 & 11 Sep 2009 & Winter & $13.51-14.15$ & $3.89-4.65$ & $0.62-1.01$ \\
4 & 16 Oct 2009 & Spring & $14.60-14.97$ & $7.63-16.39$ & $1.63-2.77$ \\
5 & 22 Sep 2010 & Spring & $16.19-16.78$ & $2.83-4.39$ & $1.54-7.27$ \\
6 & 12 Nov 2010 & Spring & $17.70-17.91$ & $4.55-6.01$ & $0.70-1.19$ \\
7 & 25 Jan 2011 & Summer & $24.10-24.56$ & $32.49-32.80$ & $2.08-4.29$ \\
8 & 31 May 2011 & Autumn & $13.57-14.29$ & $3.44-8.83$ & $2.89-3.53$ \\
\hline
\end{tabular}


(using R's library $\{\operatorname{mgvc}\}$ ); competitive model formulations were explored using different error family distributions (i.e., Gaussian, Gamma) and link functions (inverse, identity) and selected according to Akaike Information Criterium (AIC, Burnham and Anderson, 2002). Those analyses considered EPR by all dominant copepods. In a second step, the functional relationship between observed $\mathrm{EPR}_{\mathrm{AT}}$ (EPR by $A$. tonsa, only) and salinity was compared to that resulting from laboratory experimental approaches (Calliari et al., 2006). For that simple dome or humped shaped functions (e.g., Ricker curve, Bell-shaped function; Crawley, 2013), were fitted to observed $\mathrm{EPR}_{\mathrm{AT}}$. A statistically significant fit of $\mathrm{EPR}_{\mathrm{AT}}$ to a dome model was taken as a first supportive evidence of a match between laboratory and field patterns; further considerations included the coincidence in the salinity ranges for maximum $\mathrm{EPR}_{\mathrm{AT}}$ on both datasets, and the match/ mismatch in absolute $\mathrm{EPR}_{\mathrm{AT}}$ values over different salinity ranges. All statistical analyses were performed using R (R Core team, 2015) and the RKWard interface (Friedrichsmeier et al., 2015).

\section{RESULTS}

Temperature ranged between a minimum of $10.54^{\circ} \mathrm{C}$ in August 2009 and a maximum of $24.56{ }^{\circ} \mathrm{C}$ in January 2011. Salinity ranged between 2.83 in September 2010 (surface) and 32.99 in January 2011 (bottom layer) (Fig. 2). Vertical structure was evident in most cases for both temperature and salinity, but was clearer for salinity (Fig. 3). In most cases a shallow surface mixing layer encompassed the upper 2 to $3 \mathrm{~m}$ of the water column, and the clines extended to a maximum depth of between 3 and $7 \mathrm{~m}$. An exception was January 2011 when nearly homogeneous high salinity water prevailed throughout the water column. Chl-a varied between 0.62 and $7.27 \mathrm{mg} \mathrm{m}^{-3}$; cruise average values for the three stations ( \pm standard deviation) ranged from $0.8( \pm 0.2) \mathrm{mg} \mathrm{m}^{-3}$ on $12^{\text {th }}$ September 2009 (late Winter) to $4.2( \pm 2.9) \mathrm{mg} \mathrm{m}^{-3}$ on $22^{\text {nd }}$ September 2010 (early Spring) (Fig. 2).

A. tonsa was the strongly dominant copepod species throughout the period, with the exception of the January 2011 cruise when high haline conditions prevailed and dominant taxa were $P$. parvus and Oithona spp. EPR was thus measured for $A$. tonsa in all cases, except in January when it was measured for $P$. parvus. Measured EPR ranged between 6.5 and 95.7 eggs fem ${ }^{-1} \mathrm{~d}^{-1}$ (average for replicate bottles from a single station on a given cruise); cruise average values for the three stations ranged from $10.6( \pm 6.0)$ eggs fem ${ }^{-1} \mathrm{~d}^{-1}$ on $31^{\text {st }}$ May to 86 ( \pm 9.2 ) eggs fem ${ }^{-1} d^{-1}$ on $16^{\text {th }}$ October 2009 (Fig. 2); the same ranges are valid for the $\mathrm{EPR}_{\mathrm{AT}}$ data subset.
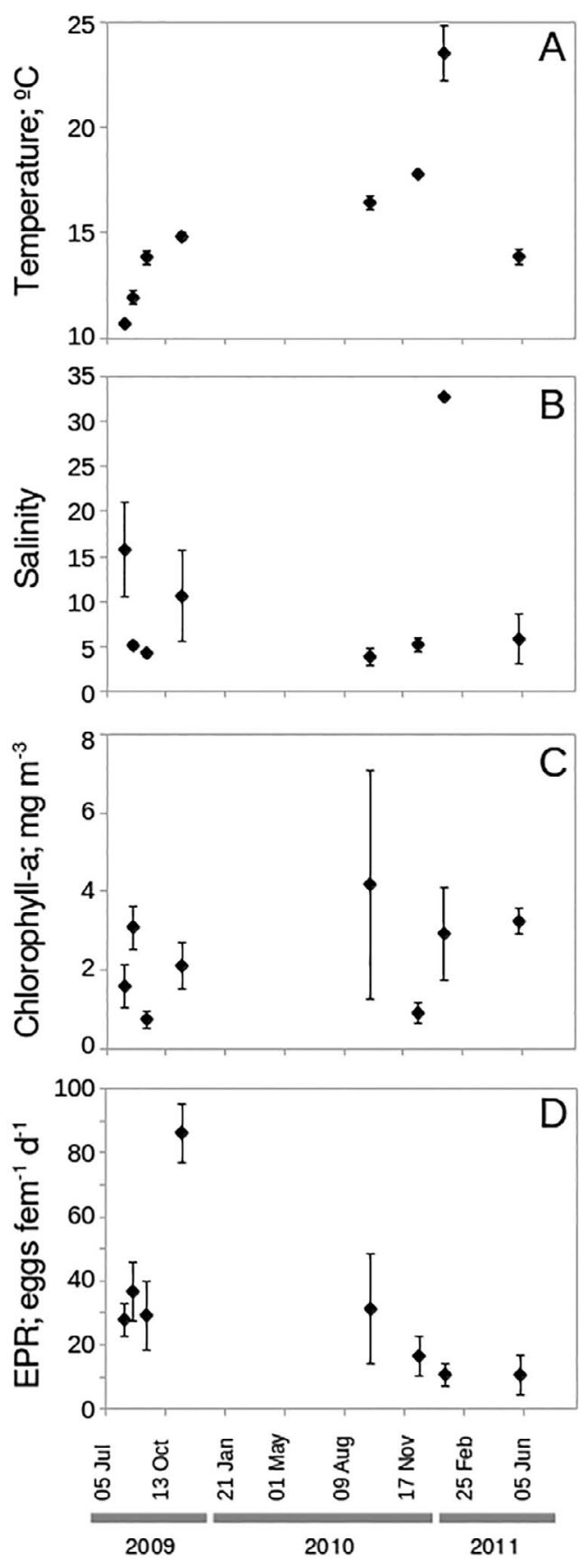

Figure 2. Time evolution of environmental variables during the study period in the Rio de la Plata estuary: A) temperature, B) salinity, and C) chlorophyll-a. Panel D) Copepods egg production rate.

Exploration of relationships between copepods' EPR and environmental variables suggested significant relationships with temperature and with salinity, but no relationship was found with chl-a (Table 2). The relationship 

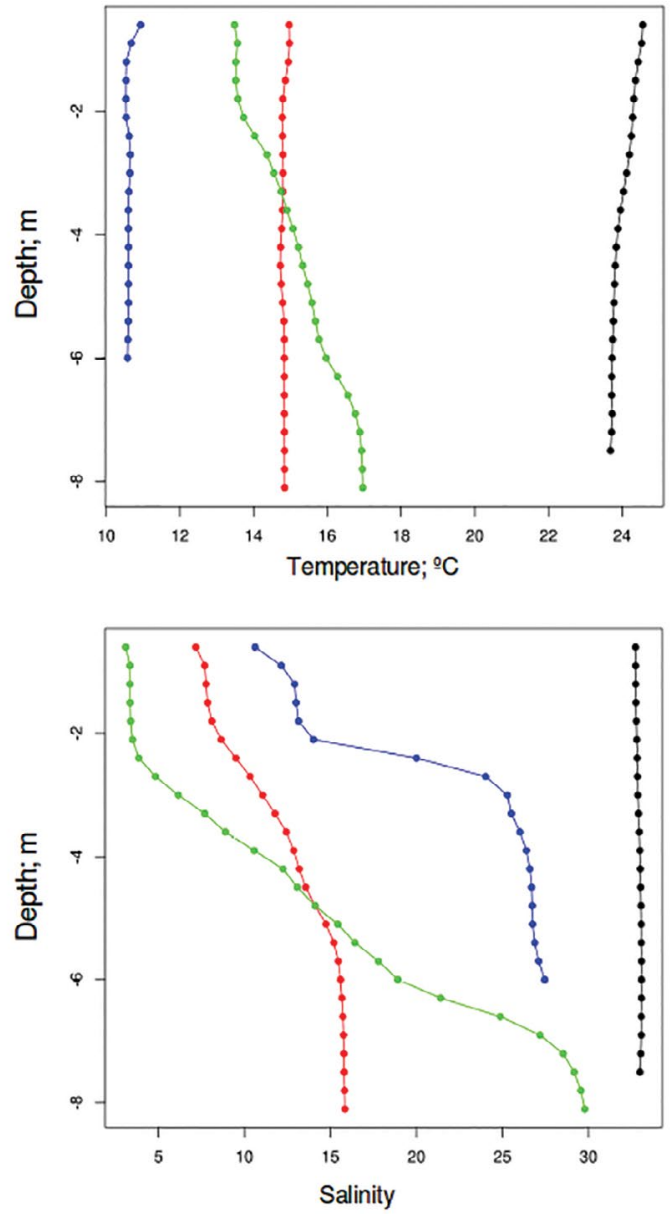

Figure 3. Examples of contrasting temperature (upper panel) and salinity (lower panel) vertical structure found during the study period in the RPE. Colour codes: blue (5 Aug 2009), red (11 Sep 2009), black (25 Jan 2011), green (31 May 2011).

between EPR and temperature was weak, though, with high scatter and a very low fraction of explained deviance. For $A$. tonsa, the plot of $\mathrm{EPR}_{\mathrm{AT}}$ vs. salinity was also noisy, and suggested a non-linear pattern compatible with a humped model and maximum EPR in the 10 - 15 salinity range (Fig. 4). No relationship was find between $E R_{A T}$ and temperature, nor between $\mathrm{EPR}_{\mathrm{AT}}$ and chl-a (Fig. 4). In particular, a linear (null) model fitted to $\mathrm{EPR}_{\mathrm{AT}}$ vs. salinity data yielded a very poor fit (non-significant slope) and was outperformed by the humped model (Fig. 4b) according to Akaike Information Criterion.

\section{DISCUSSION}

Temperature and salinity showed wide variability - approximately $14^{\circ} \mathrm{C}$ and 30 salinity units - which is expected according to the climatology of the studied region (Nagy et al., 1998; Guerrero et al., 1997). Chl-a ranged between <1 and $7 \mathrm{mg} \mathrm{m}^{-3}$, a narrower range than reported for the area (Paul and Calliari, 2017; Calliari et al., 2018). Rates of egg production measured in the present study, mostly by $A$. tons $a$, ranged between moderate and very high, in contrast with previous results (see below). A. tonsa is known to attain high biological rates under favorable environments; it is well adapted to eutrophic conditions (Paffenhöfer and Stearns, 1988), and is able to develop high consumption and EPR, i.e., higher than similarly sized congeneric species like A. clausi under similar conditions (Mauchline, 1998). Some of the $\mathrm{EPR}_{\mathrm{AT}}$ recorded here were indeed very high (i.e., 77, 85 and 95 eggs $\mathrm{fem}^{-1} \mathrm{~d}^{-1}$ ) but are not unprecedented (Jónasdóttir, 1994). Current results thus support the expected high productivity of copepods in the RPE.

The characterization of zooplankton vital rates in situ, and their relationship with environmental variables is critical to understand their role in estuarine food webs. Investigations under controlled laboratory conditions stressed the eurihalinity of $A$. tonsa by characterizing its survival (Cervetto et al., 1999), osmoregulation (Lance, 1964; Svetlichny and Hubareva, 2014), EPR, excretion, respiration and ingestion rates under wide salinity ranges (Gaudy et al., 2000; Calliari et al., 2006). Besides simplifications implicit in laboratory approaches (Bamstedt et al., 2000; Runge and Roff, 2000; Ikeda et al., 2000), in the field many factors will potentially influence growth, EPR and the general metabolism of copepods. Some well known examples are water temperature (Vidal, 1980; Gaudy et al., 2000; Castro-Longoria, 2003), food quantity and quality (Kiørboe, 1993; Ianora et al., 2004; Paffenhöfer et al.,

Table 2. GAM specification and fit for exploration of relationships between copepods EPR and environmental variables salinity, temperature and chlorophyll-a.

\begin{tabular}{lcccc}
\hline Model specification & Family (link) & $\mathrm{N}$ & $p$ & \% Deviance explained \\
\hline epr $\sim$ s(salinity) & Gamma (identity) & 23 & $<0.01$ & 34 \\
epr $\sim$ s(temperature) & Gamma (identity) & 23 & $<0.01$ & 19 \\
epr $\sim$ s(chlorophyll) & Gamma (identity) & 23 & n.s & - \\
\hline
\end{tabular}



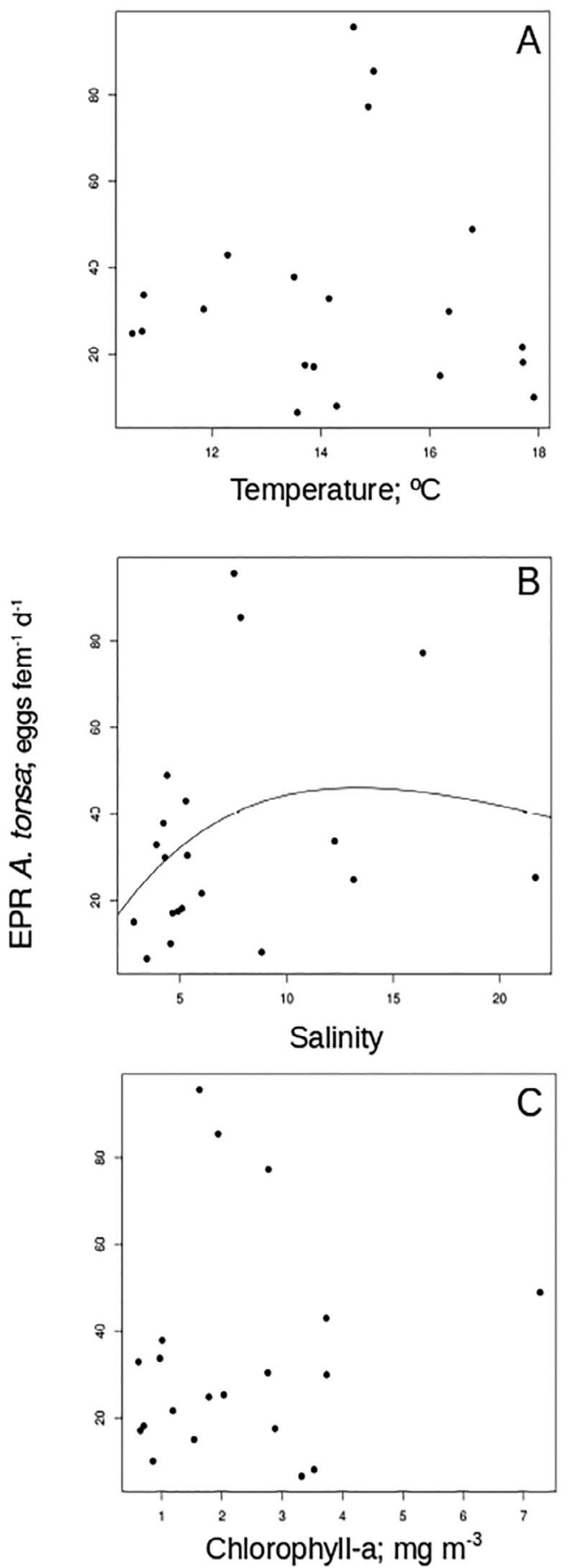

Figure 4. Scatterplot of Acartia tonsa $\mathrm{EPR}\left(\mathrm{EPR}_{\mathrm{AT}}\right)$ vs. surface temperature (upper panel), $\mathrm{EPR}_{\mathrm{AT}}$ vs. surface salinity (middle panel) and $\mathrm{EPR}_{\mathrm{AT}}$ vs. chlorophyll-a in the RPE (lower panel). In the middle panel line corresponds to Ricker model fitted to the data: $\mathrm{EPR}_{\mathrm{AT}} \sim \mathrm{a}$ * Salinity * $\exp (-\mathrm{b} *$ Salinity). Parameter values $( \pm \mathrm{SE})$ and significance: $\mathrm{a}=9.40( \pm 2.84), p<0.01 ; \mathrm{b}=0.075( \pm 0.029), p<0.05$.
2005), oxygen concentration (Vinogradov et al., 1992; Svetlichny et al., 2000). Thus, it is important to explicitly assess the extent to which patterns observed in the laboratory are valid in nature. If salinity is a first order driver of $\mathrm{EPR}_{\mathrm{AT}}$ in nature, as presumed from laboratory studies, a quantitative relationship consistent with that observed under controlled conditions should be expected in the field data.

The EPR response of $A$. tonsa vs. salinity found during the present study was noisy but generally resembled that obtained in the laboratory (Calliari et al., 2006). Both laboratory and field results described a non-linear humped pattern, with maximum $\mathrm{EPR}_{\mathrm{AT}}$ in the salinity range between 10 and 20. But there were also some differences. The relative difference between average lowest and highest rates was a bit higher in the field dataset, i.e., a factor of 1.7 for laboratory and 2.2 for field data. And actual values recorded in the field were much higher than in the laboratory, where maximum rates reached about $30 \mathrm{eggs}^{\mathrm{fem}}{ }^{-1}$ $\mathrm{d}^{-1}$. Higher dispersion of EPR $\mathrm{AT}_{\mathrm{T}}$ values in the field data set, i.e. a more noisy pattern and wider range, is generally consistent with other environmental variables acting on top of salinity to modulate EPR, a situation that by definition is avoided in controlled laboratory experimental approaches.

Most notably data sets differed in the maximum $\mathrm{EPR}_{\mathrm{AT}}$ attained. Such difference may have arisen from contrasting food conditions between experimental and field data sets. Laboratory results used as reference here were derived from measurements performed under strictly foodlimiting conditions (equivalent to $150 \mu \mathrm{gC} \mathrm{L}^{-1}$ ) where the cryptophyte Rhodomonas sp. was the single food offered. A. tonsa can prey upon autotrophic and heterotrophic organisms (Tiselius, 1989; Mauchline, 1998), and heterothrophic microplankton like ciliates and larger nanoflagellates are quantitatively important prey items under natural conditions. Such heterotrophic prey are generally present at lower abundances compared to phytoplankton, but tend to be overrepresented in the diet of omnivorous copepods (Calbet and Saiz, 2005; Broglio et al., 2003). Positive selection by copepods on microzooplankton results from optimum size range of some of their representatives, like ciliates (Bartram, 1981; Berggreen et al., 1988), improved detection and enhanced encounter rates with moving prey (Kiørboe and Visser, 1999), and also from higher nutritive value compared with phytoplankton (Stoecker and Capuzzo, 1990; Broglio et al., 2003). In the nearby Laguna de Rocha estuary the EPR range by $A$. tons a was similar to that found here $\left(11-82\right.$ eggs fem $^{-1} \mathrm{~d}^{-1}$; Calliari et al., 
$2009 \mathrm{~b}$ ), where it was estimated that on average $50 \%$ of the diet of $A$. tonsa was made up of heterotrophic items. Lack of a relationship between $\mathrm{EPR}_{\mathrm{AT}}$ and chl-a in the present investigation further suggests that phytoplankton was not the single (and probably neither the dominant) food type for A. tonsa. No quantification of total food availability existed during the present study, as the abundance of microzooplankton was not evaluated. But this same region of the RPE is known to host high densities of microzooplankton (e.g., 16ind $\mathrm{mL}^{-1}$, Boltovskoy et al., 2003). We hypothesize that during the present investigation significant amounts of high quality non-phytoplankton food added to occasionally abundant phytoplankton, thus allowing $A$. tonsa to reach the observed very high EPR. A qualitatively different result was reported for Long Island Sound (LIS; $41^{\circ} \mathrm{N}, 73^{\circ} \mathrm{W}$ ), where pigment ingestion and EPR by $A$. tonsa clearly correlated to chl-a following an hyperbolic pattern, and the relationship was strongest with the chl-a size fraction $>10 \mu \mathrm{m}$ (Dam et al., 1994). Such differences in the $\mathrm{EPR}_{\mathrm{AT}}$ vs. chl-a relationship are not surprising, as may arise from diverse factors, like: I.- a narrower chl-a range found in this study $\left(0.6-7 \mathrm{mg} \mathrm{m}^{-3}\right.$ in RPE, vs. 0.1 $12 \mathrm{mg} \mathrm{m}^{-3}$ in LIS); II.- use of total chl-a (instead of chl-a $>10 \mu \mathrm{m}$ ) as indicator of phytoplankton biomass would hinder the detection of a relationship if variability of total chl-a and the $>10 \mu \mathrm{m}$ fractions were not synchronic; and III.-the extreme salinity range observed in the present study (2.8 - 33) could have masked the effect of other variables, like chl-a.

Egg production for the whole dataset was also statistically associated to water temperature. However, that result should be taken cautiously because of: i.- the negative sign of the relationship found, which is opposite to the expected effect of temperature on metabolism and on EPR according to theoretical and empirical evidence (Vidal, 1980; Brown et al., 2004; Castro-Longoria, 2003); and ii.- the large scatter and very low fraction of variance explained by the fitted model. Both issues suggest that the observed relationship probably did not result from a specific mechanism linking temperature and EPR.

Finally, an intriguing outcome from this study is the large difference between current and previous results which had indicated much lower $\mathrm{EPR}_{\mathrm{AT}}$ in the same region within the RPE (Calliari et al., 2004; Derisio et al., 2014). In the first of these studies $\mathrm{EPR}_{\mathrm{AT}}$ ranged between 0.7 and 7.5eggs fem ${ }^{-1} \mathrm{~d}^{-1}$, with one exceptional high of 85 , and an overall mean of 6.8 eggs fem ${ }^{-1} \mathrm{~d}^{-1}$ as measured on eight occasions during a 4-months period (Calliari et al., 2004). In the second study, $\mathrm{EPR}_{\mathrm{AT}}$ varied between 2.4 and 14.9eggs fem $^{-1} \mathrm{~d}^{-1}$ (mean of 8.6) as measured at 11 stations during a single cruise (Derisio et al., 2014). On both studies the ranges of salinity and temperature were similar to those recorded here, and so that discrepancy can not be attributed to such environmental variables. Based on current information it is unwise to speculate over several other factors that could be linked to observed differences, and that is clearly a matter that deserves further attention.

In summary, egg production rates by copepods in the RPE were high and occasionally very high, similar to maximum values recorded in other estuaries and coastal ecosystems for this species, but clearly above rates earlier reported for it in this same estuary. Salinity was found to be a significant forcing variable for $\mathrm{EPR}_{\mathrm{AT}}$, a response characterized by a humped pattern with maximum values in the 10 - 20 salinity range, to a large extent consistent with previous findings from laboratory-based studies. Future studies should focus on the contribution of heterotrophic components in the diet of copepods within the RPE, which is a factor that may exert a strong influence on the variability of copepod productivity.

\section{ACKNOWLEDGEMENTS}

We acknowledge MSc. M. Vera and crew of Alba for their help during field work. This investigation was funded by Marie Curie Actions grant to D. Calliari (Contract MIIFR-CT-2005-980031 PCFluCS, FP6 European Union), Comisión Sectorial de Investigación Científica (Universidad de la República, Uruguay) Grant Grupos i+d 1037 and Agencia Nacional de Investigación e Innovación (Uruguay) through SNI grants to D. Calliari and L. Rodriguez-Graña, and postgraduation scholarships to N. Espinosa and M. Martínez. Suggestions by Associate Editor Dr. H. Dam on a previous version contributed to improve this paper and are greatly appreciated.

\section{REFERENCES}

ACHA, E. M., MIANZÁN, H. W., LASTA, C. A. \& GUERRERO, R. A. 1999. Estuarine spawning of the whitemouth croaker Micropogonias furnieri in the Río de la Plata, Argentina. Marine and Freshwater Research, 50, 57-65.

AGUILERA, V. M., VARGAS, C. A. V., LARDIES, M. A. \& POUPIN, M. J. 2016. Adaptive variability to low-pH river discharges in Acartia tonsa and stress responses to high ${ }_{P} \mathrm{CO}_{2}$ conditions. Marine Ecology, 37, 215-226.

ATTRILL, M. J. 2002. A testable linear model for diversity trends in estuaries. Journal of Animal Ecology, 71, 262-269. 
BÅMSTEDT, U., GIFFORD, D. J., IRIGOIEN, X., ATKINSON, A. \& ROMAN, M. 2000. Feeding. In: HARRIS, R., WIEBE, P., LENZ, J., SKJOLDAL, H. R. \& HUNTLEY, M. (eds.) Zooplankton Methodology Manual. London: ICES/Academic Press.

BARTRAM, W. C. 1981. Experimental development of a model for the feeding of neritic copepods on phytoplankton. Journal of Plankton Research, 3, 25-51.

BERGGREEN, U., HANSEN, B. \& KIØRBOE, T. 1988. Food size spectra, ingestion and growth of the copepod Acartia ton$s a$ during development: Implications for determination of copepod production. Marine Biology, 99, 341-352.

BERASATEGUI, A. D., MENU MARQUE, S., GÓMEZ-ERACHE, M., RAMÍREZ, F. C., MIANZAN, H. W. \& ACHA, E. M. 2006. Copepods assemblages in a highly complex hydrographic region. Estuarine, Coastal and Shelf Science, 66, 483-492.

BERASATEGUI, A. A., FERNANDEZ-SEVERINI, M. D., MENENDEZ, M. C., BIANCALANA, F., DUTTO, M. S., GUINDER, V., LOPEZ-ABBATE, M. C., CHAZARRETA, J. \& HOFFMEYER, M. S. 2016. Reproductive trade-off of the copepod Acartia tonsa in a hypersaline estuary of Southwestern Atlantic. Temporal variations in the morphology of eggs. Marine Biology Research, 12, 817-829.

BIANCHI, T. 2007. Biogeochemistry of Estuaries, Oxford, Oxford University Press.

BOLTOVSKOY, D., KOGAN, M., ALDER, V. A. \& MIANZAN, H. 2003. First record of a brackish radiolarian (Polycystina): Lophophaena rioplatensis $\mathrm{n}$. $\mathrm{sp}$. in the Río de la Plata estuary. Journal of Plankton Research, 25, 1551-1559.

BROGLIO, E., JÒNASDÓTTIR, S. H., CALBET, A., JAKOBSEN, H. H. \& SAIZ, E. 2003. Effect of heterotrophic versus autotrophic food on feeding and reproduction of the calanoid copepod Acartia tonsa: relationship with prey fatty acid composition. Aquatic Microbial Ecology, 31, 267-278.

BROWN, J. H., GILLOOLY, J. F., ALLEN, A. P., SAVAGE, V. M., WEST, G. B. 2004. Toward a metabolic theory of ecology. Ecology, 85, 1771-1789.

BURNHAM, K. P. \& ANDERSON, D. R. 2002. Model Selection and Multimodel Inference: A Practical Information- Theoretic Approach, Berlin, Springer.

CALBET, A. \& SAIZ, E. 2005. The ciliate-copepod link in marine ecosystems. Aquatic Microbial Ecology, 38, 157-167.

CALLIARI, D., CERVETTO, G. \& CASTIGLIONI, R. 2004. Summertime herbivory and egg production by Acartia tonsa at the Montevideo coast - Rio de la Plata. Ophelia, 58, 115-128.

CALLIARI, D., ANDERSEN, C. M, THOR, P., GOROKHOVA, E. \& TISELIUS, P. 2006. Salinity modulates the energy balance and reproductive success of co-occurring copepods Acartia tonsa and A. clausi in different ways. Marine Ecology Progress Series, 312, 177-188.

CALLIARI, D., BRUGNOLI, E., FERRARI, G. \& VIZZIANO, D. 2009a. Phytoplankton distribution and production along a wide environmental gradient in the South-West Atlantic off Uruguay. Hydrobiologia, 620, 47-61.

CALLIARI, D., BRITOS, A. \& CONDE, D. 2009b. Testing the relationship between primary production and Acartia tonsa grazing pressure in an estuarine lagoon. Journal of Plankton Research, 31, 1045-1058.
CALLIARI, D. L., GÓMEZ-ERACHE, M., VIZZIANO-CANTONNET, D. \& ALONSO, C. 2018. Near-Surface Biogeochemistry and Phytoplankton Carbon Assimilation in the Rio de la Plata Estuary. In: HOFFMEYER, M. S., SABATINI, M. E., BRANDINI, F., CALLIARI, D., SANTINELLI, N. H. (eds.) Plankton Ecology of the Southwestern Atlantic From the Subtropical to the Subantarctic Realm. Cham: Springer International Publishing AG.

CASTRO-LONGORIA, E. 2003. Egg production and hatching success of four Acartia species under different temperature and salinity regimes. Journal of Crustacean Biology, 23, 289-299.

CERVETTO, G., PAGANO, M. \& GAUD, R. 1995. Feeding behaviour and migrations in a natural population of the copepod Acartia tonsa. Hydrobiologia, 300, 237-248.

CERVETTO, G., GAUDY, R. \& PAGANO, M. 1999. Influence of salinity on the distribution of Acartia tonsa (Copepoda, Calanoida). Journal of Experimental Marine Biology and Ecology, 239, 33-45.

CRAWLEY, M. J. 2013. The R book, Chichester, John Wiley \& Sons.

DAM, H. G., PETERSON, W. T. \& BELLANTONI, D. C. 1994. Seasonal feeding and fecundity of the calanoid copepod Acartia tonsa in Long Island Sound: is omnivory important to egg production? Hydrobiologia, 292, 191-199.

DAY, J. W. KEMP, W. M., YÁÑEZ-ARANCIBIA, A. \& CRUMP, B. C. 2013. Estuarine Ecology $2^{\text {nd }}$ edition, WileyBlackwell, Hoboken. 568 p.

DERISIO, C., BRAVERMAN, M., GAITÁN, E., HOZBOR, C., RAMÍREZ, F., CARRETO, J., BOTTO, F., GAGLIARDINI, D. A., ACHA, E. M. \& MIANZAN, H. 2014. The turbidity front as a habitat for Acartia tonsa (Copepoda) in the Río de la Plata, Argentina-Uruguay. Journal of Sea Research, 85, 197-204.

FRIEDRICHSMEIER, T., ECOCHARD, P., ROEDIGER, S., KAPAT, P., MICHALKE, M., ROEDIGER, S. 2015. Interfaz gráfica para el lenguaje estadístico R, Licencia Publica General de GNU, available at: http://rkward.kde.org

GAUDY, R., CERVETTO, G. \& PAGANO, M. 2000. Comparison of the metabolism of Acartia clausi and A. tonsa: influence of temperature and salinity. Journal of Experimental Marine Biology and Ecology, 247, 51-65.

GUERRERO, R., ACHA, M. E., FRAMIÑAN, M. B. \& LASTA, C. 1997. Physical oceanography of the Río de la Plata Estuary. Continental Shelf Research, 17, 727-742.

HOFFMEYER, M. S. 2004. Decadal change in zooplankton seasonal succession in the Bahía Argentina, following introduction of two zooplankton species. Journal of Plankton Research, 26, 181-189.

HUBAREVA, E., SVETLICHNY, L., KIDEYS, A., ISINIBILIR, M., 2008. Fate of the Black Sea Acartia clausi and Acartia tonsa (Copepoda) penetrating into the Marmara Sea through the Bosphorus. Estuarine Coastal and Shel Science, 76, 131-140.

IANORA, A., MIRALTO, A., POULET, S. A., CAROTENUTO, Y., BUTTINO, I., ROMANO, G., CASOTTI, R., POHNERT, G., WICHARD, T., COLUCCI-D'AMATO, L., TERRAZZANO, G. \& SMETACEK, V. 2004. Aldehyde suppression of copepod recruitment in blooms of a ubiquitous planktonic diatom. Nature, 429, 403-407. 
IKEDA, T., TORRES J. J., HERNÁNDEZ-LEÓN, S. \& GEIGER, S. P. 2000. Metabolism. In: HARRIS, R. P., WIEBE, P. H., LENZ, J., SKJOLDAL, H. R. \& HUNTLEY, M. (eds.) ICES zooplankton methodology manual. San Diego: Academic Press.

JÓNASDÓTTIR, S. H. 1994. Effects of food quality on the reproductive success of Acartia tonsa and Acartia hudsonica: laboratory observations. Marine Biology, 121, 67-81.

KIØRBOE, T. 1993. Turbulence phytoplankton cell size and the structure of pelagic food webs. Advances in Marine Biology, 29, 1-72.

KIØRBOE, T. \& VISSER, A. W. 1999. Predator and prey perception in copepods due to hydromechanical signals. Marine Ecology Progress Series, 179, 81-95.

LANCE, J. 1964. Feeding of zooplankton in diluted sea-water. $\mathrm{Na}$ ture, 201, 100-101.

LANCE, J. 1965. Respiration and osmotic behavior of the copepod Acartia tonsa in diluted sea water. Comparative Biochemistry and Physiology, 14, 155-165.

LEANDRO, S. M., MORGADO, F., PEREIRA, F. \& QUEIROGA, H. 2007. Temporal changes of abundance, biomass and production of copepod community in a shallow temperate estuary (Ria de Aveiro, Portugal). Estuarine Coastal and Shelf Science, 74, 215-222.

LERCARI, D., HORTA, S., MARTINEZ, G., CALLIARI, D. \& BERGAMINO, L. 2015. A food web analysis of the Río de la Plata estuary and adjacent shelf ecosystem: trophic structure, biomass flows, and the role of fisheries. Hydrobiologia, 742, 39-58. DOI: 10.1007/s10750-014-1964-8

MAUCHLINE, J. 1998. The biology of calanoid copepods, San Diego, Academic Press.

MUXAGATA, E., AMARAL, W. J. A., BARBOSA, C. N. 2012. Acartia tonsa production in the Patos Lagoon estuary, Brazil. ICES Journal of Marine Science, 69, 475-482.

NAGY, G., MARTÍNEZ, C. M., CAFFERA, R. M., PEDROSA, G., FORBES, E. A., PERDOMO, A. C. \& LOPEZ LABORDE, J. 1998. Marco hidrológico y climático del Río de la Plata. In: WELLS, P. \& DABORN, G. (eds). El Río de la Plata. Una Revisión Ambiental. Un informe de Antecedentes del Proyecto EcoPlata. Halifax: Dalhousie University.

NORBIS, W. \& VEROCAI, J. 2005. Presence of two whitemouth croaker (Micropogonias furnieri, Pisces: Sciaenidae) groups in the Río de la Plata spawning coastal area as consequence of reproductive migration. Fisheries Research, 74, 134-141.

PAFFENHÖFER, G. A. \& STEARNS, D. E. 1988. Why is Acartia tonsa (Copepoda: Calanoida) restricted to nearshore environments? Marine Ecology Progress Series, 42, 33-38.

PAFFENHÖFER, G. A., IANORA, A., MIRALTO, A., TURNER, J. T., KLEPPEL, G. S., D'ALCALA, M. R., CASOTTI, R., CALDWELL, G. S., POHNERT, G., FONTANA, A., MULLER-NAVARRA, D., JÓNASDÓTTIR, S. H., ARMBRUST, V., BAMSTEDT, U., BAN, S., BENTLEY, M. G., BOERSMA, M., BUNDY, M., BUTTINO, I., CALBET, A., CARLOTTI, F., CAROTENUTO, Y., D'IPPOLITO, G., FROST, B., GUISANDE, C., LAMPERT, W., LEE, R. F., MAZZA, S., MAZZOCCHI, M. G., NEJSTGAARD, J. C., POULET, S. A., ROMANO, G., SMETACEK, V., UYE, S., WAKEHAM, S., WATSON, S. \& WICHARD, T. 2005. Colloquium on diatom-copepod interactions. Marine Ecology Progress Series, 286-293-305.
PARSONS, T. R., MAITA, Y. \& LALLI, C. 1984. A manual of chemical and biological methods for seawater analysis, Oxford, Pergmon Press.

PAUL, S. \& CALLIARI, D. 2017. Salinity and temperature tolerances of Neomysis americana (Crustacea: Mysida) sub adults: Perspectives on vulnerability, and distribution in South America. Journal of Experimental Marine Biology and Ecology, 486, 373-378.

R CORE team 2015. R: A Language and Environment for Statistical Computing. R Foundation for Statistical Computing. Vienna, Austria, https://www.R-project.org. Accessed November 152018

RICE, E., DAM, H. G., STEWART, G. M. 2015. Impact of climate change on estuarine zooplankton: surface water warming in Long Island Sound is associated with changes in copepod size and community structure. Estuaries and Coasts, 38, 13-23.

RUNGE, J. A. \& ROFF, J. C. 2000. The measurement of growth and reproductive rates. In: HARRIS, R. P., WIEBE, P. H., LENZ, J., SKJOLDAL, H. R. \& HUNTLEY, M. (eds.) ICES Zooplankton methodology manual. London: Academic Press.

STOECKER, D. K. \& CAPUZZO, J. M. 1990. Predation on Protozoa: its imortance to zooplankton. Journal of Plankton Research, 12, 891-908.

SVETLICHNY, L. S., HUBAREVA, E. S., ERKAN, F. \& GUCU, A. C. 2000. Physiological and behavioral aspects of Calanus euxinus females (Copepoda: Calanoida) during vertical migration across temperature and oxygen gradients. Marine Biology, 137, 963-971.

SVETLICHNY, L. S. \& HUBAREVA, E. S. 2014. Salinity tolerance of alien copepods Acartia tonsa and Oithona davisae in the Black Sea. Journal of Experimental Marine Biology and Ecology, 461, 201-208.

TISELIUS, P. 1989. Contribution of aloricate ciliates to the diet of Acartia clausi and Centropages hamatus in coastal waters. Marine Ecology Progress Series, 56, 49-56.

VIDAL, J. 1980. Physioecology of Zooplankton. I. Effects of Phytoplankton Concentration, Temperature, and Body Size on the Growth Rate of Calanus pacificus and Pseudocalanus sp. Marine Biology, 56, 111-134.

VINOGRADOV, M. E, ARASHKEVICH, E. G. \& ILCHENKO, S. V. 1992. The ecology of the Calanus ponticus population in the deeper layer of its concentration in the Black Sea. Journal of Plankton Research, 14, 447-458.

WASMUND, N., TOPP, I. \& SCHORIES, D. 2006. Optimising the storage and extraction of chlorophyll samples. Oceanologia, $48,125-144$. 